\title{
The Bees Algorithm Approach to Determining SMC Controller Parameters for the Position Control of a SCARA Robot Manipulator
}

\author{
Sinan İlgen ${ }^{1 *}$, Akif Durdu ${ }^{2}$, Erdi Gülbahçe ${ }^{3}$, Abdullah Çakan $^{4}$, Mete Kalyoncu $^{5}$ \\ ${ }^{1 *}$ KTO Karatay University, Faculty of Engineering and Natural Sciences, Departmant of Mechatronics Engineering, Konya, Turkey, (ORCID: 0000-0002-5062-9523), \\ sinan.ilgen@karatay.edu.tr \\ ${ }^{2}$ Konya Technical University, Faculty of Engineering and Natural Sciences, Departmant of Electrical and Electronics Engineering, Konya, Turkey, (ORCID: 0000- \\ 0002-5611-2322), adurdu@ktun.edu.tr \\ ${ }^{3}$ KTO Karatay University, Faculty of Engineering and Natural Sciences, Departmant of Mechatronics Engineering, Konya, Turkey, (ORCID: 0000-0002-6489-2314), \\ erdi.gulbahce@karatay.edu.tr \\ ${ }^{4}$ Konya Technical University, Faculty of Engineering and Natural Sciences, Departmant of Mechanical Engineering, Konya, Turkey, (ORCID: 0000-0003-3923-4069), \\ acakan@ktun.edu.tr \\ 5 Konya Technical University, Faculty of Engineering and Natural Sciences, Departmant of Mechanical Engineering, Konya, Turkey, (ORCID: 0000-0002-2214-7631), \\ mkalyoncu@ktun.edu.tr
}

(First received 19 February 2021 and in final form 23 January 2022)

(DOI: $10.31590 /$ ejosat.883266)

ATIF/REFERENCE: İlgen, S., Durdu, A., Gülbahçe, E., Çakan, A. \& Kalyoncu, M. (2022). The Bees Algorithm Approach to Determining SMC Controller Parameters for the Position Control of a SCARA Robot Manipulator. European Journal of Science and Technology, (33), 267-273.

\begin{abstract}
In this study, position control of a SCARA robot manipulator is investigated using the sliding mode control (SMC) method based on parameter optimization using The Bees Algorithm. The modeling the SCARA manipulator is conducted in MSC Adams and the control implementation is carried out in MATLAB software. The numerical model of the SCARA manipulator is acquired by setting up a virtual prototype on MSC Adams software. In addition, the inverse kinematic equations of the SCARA manipulator are formed using Matlab/Simulink software in order to check the accuracy of the created virtual prototype. In addition, the SMC controller parameters are optimized with The Bees Algorithm to get better results. Then, the control performance of the system is examined on the virtual prototype using MSC Adams-MATLAB co-simulation. Moreover, Genetic Algorithm, another meta-heuristic method, is used for parameter optimization and the performance of The Bees Algorithm is compared with the results obtained. As a result, it has been observed that The Bees Algorithm can be used in studies related to the control of robotic systems.
\end{abstract}

Keywords: Genetic Algorithm, Optimization, Position control, Robot manipulator, Sliding mode control, Simulation, The Bees Algorithm.

\section{Bir SCARA Robot Manipülatörün Konum Kontrolü için SMC Denetleyici Parametrelerini Belirlemeye Yönelik Arı Algoritması Yaklaşımı}

$\ddot{O} z$

Bu çalışmada, SCARA tip bir robot manipülatörün konum kontrolü, Arı algoritması kullanılarak parametre optimizasyonuna dayanan kayan kipli kontrol (SMC) yöntemi kullanılarak incelenmiştir. SCARA manipülatörün modellenmesi MSC Adams'ta yapılmış ve kontrol uygulaması MATLAB yazılımında gerçekleştirilmiştir. SCARA manipülatörün sayısal modeli, MSC Adams yazılımı üzerinde sanal bir prototip kurularak elde edilmiştir. Ayrıca, oluşturulan sanal prototipin doğruluğunu kontrol etmek için SCARA manipülatörün ters kinematik denklemleri Matlab/Simulink yazılımı kullanılarak oluşturulmuştur. Ek olarak, daha iyi sonuçlar elde etmek için SMC kontrolcünün parametreleri Arı Algoritması ile optimize edilmiştir. Ardından MSC Adams-MATLAB eş zamanlı simülasyonu kullanılarak sanal prototip üzerinde sistemin kontrolcü performansı incelenmiştir. Ayrıca, parametre optimizasyonu için bir başka meta-sezgisel yöntem olan Genetik Algoritma kullanılmış ve elde edilen sonuçlar ile Arı Algoritmasının performansı karşılaştırılmıştır. Sonuç olarak, Arı Algoritmasının robotik sistemlerin kontrolü ile ilgili çalışmalarda kullanılabilir olduğu gözlemlenmiştir.

Anahtar Kelimeler: Arı algoritması, Genetik Algoritma, Kayan kipli kontrol, Optimizasyon, Robot Manipülatör, Simülasyon, Konum kontrolü.

* Corresponding Author: sinan.ilgen@karatay.edu.tr 


\section{Introduction}

Robot mechanisms are obtained by connecting rigid bodies to each other with the joints which provide movement. They have high mobility and extensive working areas; thus, they are useful in various industrial processes. SCARA robot is one of the attractive fields in industrial automation systems. SCARA robots are commonly used for positioning and handling of materials in industrial applications. Latest technological work has enhanced the efficiency of the SCARA robot control strategy that can be used to replace humans in dangerous, complicated, and repetitive tasks. In robotics, researchers focus on improving of controller performance of the robot manipulator systems in their studies. Modelling and control are a main concern for SCARA robots due to the nonlinearities and complex physical structure. Generally, different types of controllers provide different output performance for the movement of robot. For the control of SCARA robots, controller structures such as PID and fuzzy logic control (FLC) are mostly used. In addition, various combinations of different controller structures are used in the studies (Tarmizi, 2014).

Different researchs on SCARA robots are mentioned in the literature review. But in this paper, the most significant and similar studies are considered and given. Modeling and control of SCARA type robot manipulators is studied by researchers. In (Şahin, 2006), trajectory control of a SCARA manipulator is reported and the control process is carried out with the PID controller structure. In (Sayg1l1, 2006), design and 3-D simulation of the SCARA robot is presented. Ogulmus et. al. presents dynamic model and position control of a SCARA robot type 3D printer system (Ogulmuş, Çakan, \& Tınkır, 2016). Other studies on modeling and control of SCARA robot manipulators are also analyzed (Bruzzone \& Bozzini, 2011; Go \& Lee, 2001; Surapong \& Mitsantisuk, 2016; Urrea, Cortés, \& Pascal, 2016; Urrea \& Kern, 2012; Wang, Liu, Wei, Xu, \& Zhang, 2014).

It has been known that various optimization methods are widely used to improve the controller performance of robot manipulators. These optimization methods are used alone or in a hybrid way. There are many optimization studies in the literature regarding the control of robot manipulators. In these studies, many different optimization methods such as Gravitational Search Algorithm (GSA), Genetic Algorithm (GA), D Star (D*) Algorithm, Simulated Annealing (SA), Gray Wolf Optimizer (GWO), Particle Swarm Optimization (PSO), Differential Evolution (DE) Algorithm, Whale Optimization Algorithm (WOA) have been studied (Beşkirli \& Tefek, 2019; Demydyuk \& Hoshovs'ka, 2019; Erdogmus \& Toz, 2012; Loucif, Kechida, \& Sebbagh, 2020; Nadir \& Mohammed, 2018; Oliveira, Oliveira, Boaventura-Cunha, \& Pinho, 2017; Qiang, Xuhua, Ting, Xiaoxia, \& Jianpei, 2019; Raheem \& Hameed, 2019; Soltanpour \& Khooban, 2013; Zhou, Wang, Zhu, Wang, \& Yang, 2019).

In this study, the position control of a SCARA type robot manipulator is carried out to develope the control performance using The Bees Algorithm which is optimizing the SMC controller parameters which is variously used in robotic studies (Ölgün \& Tilki, 2020). The modelling and control implementation is conducted by MSC Adams and MATLAB programs which are run simultaneously. In the optimum SMC controller design based on The Bees Algorithm, the objective function is determined as the error that occurs in the system e-ISSN: 2148-2683 response. In addition, the optimization process is also carried out with a Genetic Algorithm and a performance comparison is made between the algorithms. When the simulation results of the controlled system, it is observed that the optimization method with The Bees Algorithm is as satisfactory as the Genetic Algorithm in position control.

This paper is organized as follows. The introduction is given in Section I. In Section II, the system modelling, the controller structure, and the algorithms used are reported. Co-simulation control results are given in Section III. Finally, conclusions are reported in Section V.

\section{Material and Method}

\subsection{Modelling of SCARA Robot Manipulator}

The dynamic model of the SCARA manipulator is obtained using MSC Adams, which is software used to develop and simulate the multi-body rigid dynamics of systems. The 3-D model of the SCARA robot manipulator created in MSC Adams environment is shown in Fig. 1. Also, the physical properties of the model are shown in Fig. 2.

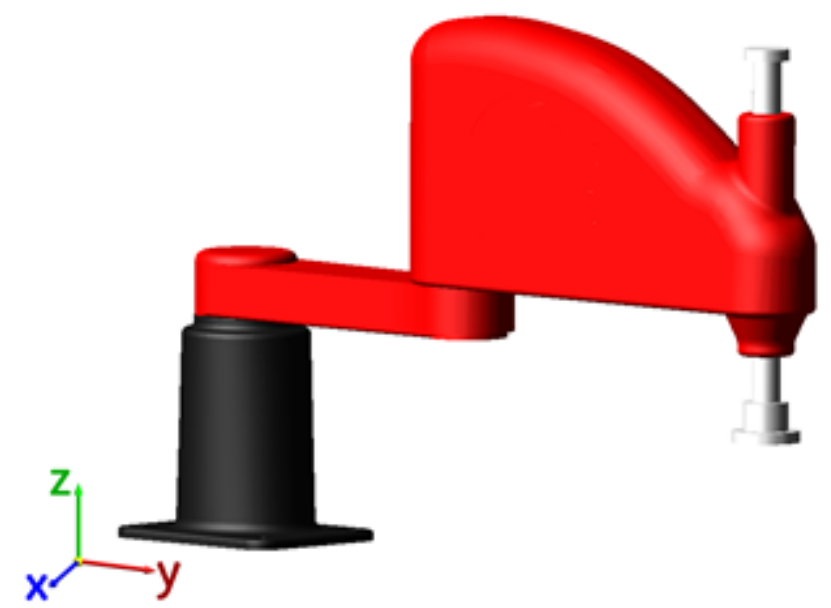

Fig. 1. 3-D model of the SCARA manipulator

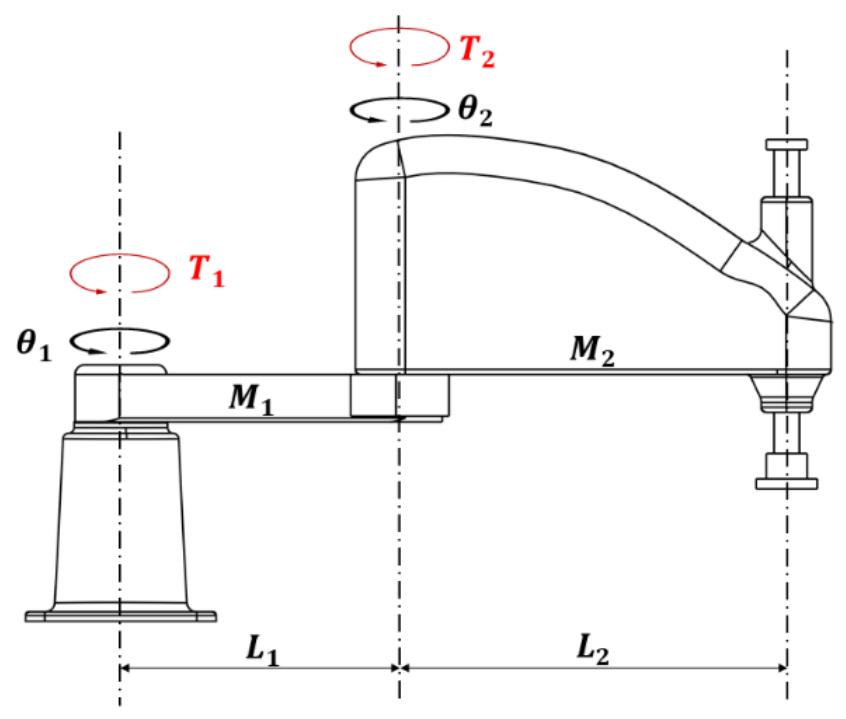

Fig. 2. 2-D model of the SCARA manipulator

In the SCARA maipulator, there are two inputs (torques of actuators) for the robot manipulator. On the other hand, it has 
four outputs (angles of the joints and, $\mathrm{x}$ and $\mathrm{y}$ component of the end position of the model). In Table 1, some properties of the robot manipulator are defined. Additionally, the mass moment of inertia of each link is $0.018 \mathrm{~kg} . \mathrm{m}^{2}$ and $0.0168 \mathrm{~kg} . \mathrm{m}^{2}$, respectively.

Table 1. Properties of the SCARA robot manipulator

\begin{tabular}{c|c|c|c|c|c|c|c}
\hline $\boldsymbol{M}_{\boldsymbol{1}}$ & $\boldsymbol{M}_{\boldsymbol{2}}$ & $\boldsymbol{L}_{\boldsymbol{1}}$ & $\boldsymbol{L}_{\boldsymbol{2}}$ & $\boldsymbol{T}_{\boldsymbol{1}}$ & $\boldsymbol{T}_{\boldsymbol{2}}$ & $\boldsymbol{\theta}_{\boldsymbol{1}}$ & $\boldsymbol{\theta}_{\boldsymbol{2}}$ \\
\hline 0.588 & 3.465 & 0.15 & 0.2 & $\mathrm{Nm}$ & $\mathrm{Nm}$ & Degree & Degree \\
$\mathrm{kg}$. & $\mathrm{kg}$. & $m$. & $m$. & & & & \\
\hline
\end{tabular}

To control of the robot manipulator, two controllers are designed between both angles of the joints and torques of actuators. For designing of the SMC controller, $2^{\text {nd }}$ order transfer functions are required between $\theta_{1}-\mathrm{T}_{1}$ and between $\theta_{2}-\mathrm{T}_{2}$. The required transfer functions of the system for the controller design are acquired as presented method (using Matlab/System Identification Toolbox) in our previous study (İlgen, 2019; İlgen, Durdu, Gülbahçe, \& Çakan, 2018).

\subsection{Implementation of SMC Controller Structures}

For the $1^{\text {st }}$ joint, (1) and (2) are attained if the inverse Laplace transform is applied, and some simplifications are done in the transfer function to return to time domain. Also, the sliding surface can be specified in (3).

$$
\begin{gathered}
\ddot{\theta}_{1}(t)+F \dot{\theta_{1}}(t)+Q \theta_{1}(t)=A T_{1}(t) \\
\ddot{\theta_{1}}(t)=-F \dot{\theta_{1}}(t)-Q \theta_{1}(t)+A T_{1}(t) \\
s=\dot{e}(t)+\lambda_{1} e(t)=\dot{\theta_{1 d}}(t)-\dot{\theta_{1}}(t)+\lambda_{1}\left(\theta_{1 d}(t)-\theta_{1}(t)\right)
\end{gathered}
$$

The derivative of (3) is shown in (4). The first and second derivatives of $\theta_{1 \mathrm{~d}}(\mathrm{t})$ are zero if $\theta_{1 \mathrm{~d}}(\mathrm{t})$ is considered constant. Hence (4) is rewritten as in (5).

$$
\begin{aligned}
& \dot{s}=\ddot{\theta_{1 d}}(t)-\ddot{\theta_{1}}(t)+\lambda_{1}\left(\dot{\theta_{1 d}}(t)-\dot{\theta_{1}}(t)\right) \\
& \dot{s}=-\ddot{\theta}_{1}(t)+\lambda_{1}\left(-\dot{\theta_{1}}(t)\right)=-K \cdot \operatorname{sign}(s)
\end{aligned}
$$

The $T_{1}(t)$ control signal can be produced in (6) if (2) is substituted in (5).

$$
T_{1}(t)=-\frac{1}{A_{1}}\left[\left(F_{1}-\lambda_{1}\right) \dot{\theta_{1}}(t)+Q_{1} \theta_{1}(t)+K_{1} \operatorname{sign}(s)\right](6)
$$

When the same procedures are made for the $2^{\text {nd }}$ joint $T_{2}(t)$ control signal can be produced as in (7).

$$
T_{2}(t)=-\frac{1}{A_{2}}\left[\left(F_{2}-\lambda_{2}\right) \dot{\theta_{2}}(t)+Q_{2} \theta_{2}(t)+K_{2} \operatorname{sign}(s)\right](7)
$$

In these control signals $\left(\mathrm{T}_{1}\right.$ and $\left.\mathrm{T}_{2}\right), \mathrm{A}_{1}, \mathrm{~A}_{2}, \mathrm{~F}_{1}, \mathrm{~F}_{2}, \mathrm{Q}_{1}$ and $\mathrm{Q}_{2}$ are the parameter values taken from the transfer functions (İlgen, 2019). On the other hand, $K_{1}, K_{2}, \lambda_{1}$ and $\lambda_{2}$ are the controller coefficients. These coefficients are firstly obtained by trial and error. Then, to get better results, the coefficients are optimized by The Bees Algorithm.

\subsection{Optimization of SMC Controller Parameters with The Bees Algorithm}

The Bees Algorithm is a heuristic search algorithm which is a population-based. It is included that mimics the collective intelligence characteristics of bees such as resource-seeking behaviour, learning, recall, and information sharing. (D. Pham et al., 2005; D. T. Pham et al., 2006). Pham and Kalyoncu reported The Bees Algorithm based Fuzzy Logic and PID controllers to control a flexible link robot manipulator. These studies are the first theoretical and experimental studies of controller optimization using The Bees Algorithm (D. Pham \& Kalyoncu, 2009; D. Pham, Koç, Kalyoncu, \& Tınkır, 2008). Şen and Kalyoncu designed PID and LQR controller with The Bees Algorithm for the inverted pendulum system in order to examine the performance of The Bees Algorithm in controller optimization (Sen \& Kalyoncu, 2015, 2016). As a result of the studies, it is observed that The Bees Algorithm gives successful results in the optimization of the controller parameters and the position control of the system is improved compared to the traditional methods. In addition, it is stated that The Bees Algorithm enables the adjustment of transient and steady state response criterias (settling time, maximum overshoot, steady state error, etc.) of the system.

First proposed by DT Pham et al in 2006, the parameters belonging to the basic Bee Algorithm are as follows: the number of explorer bees (n), the number of most suitable regions among the $\mathrm{n}$ points visited $(\mathrm{m})$, the number of elite regions in the selected $m$ regions (e), the number of bees sent to the best $\mathrm{e}$ region (nep), the number of bees sent to the remaining (m-e) area (nsp), the region size (ngh) and number of stop criteria / iterations (itr).

The stages of The Bees Algorithm could be explained as follows. The Bee Algorithm starts with the random placement of $\mathrm{n}$ explorer bees in the research area. Then, the compatibility of the points visited by the explorer bees with respect to each other is evaluated in the 2 nd step. $m$ regions with more suitability values among $\mathrm{n}$ regions are selected in step 3. In steps 4 and 5, elite regions (e) with the best fit and the remaining regions (m-e) are selected among $\mathrm{m}$ regions. Neighbourhood search size (ngh) of these regions is defined. For neighbourhood search in selected regions (search for the most suitable points in the region), a detailed search is made by sending more follower bees (nep) to the best e region, which represents more promising solutions, and less follower bees (nsp) to other regions. Within each region, the bee with the most suitable value is selected. In the 6th, 7th, and 8th steps, except for The Bees with the most suitable value in each region, other bees are split from the research area. Other bees in the population (n-m) are randomly located back into the research space to discover new possible solutions. The optimization is continued until the stop criterion (itr) is met. At the end of each iteration, the new population consists of two parts, the representatives of each selected region and the random search scout bees. The main steps of The Bees Algorithm is given in Fig. 3. (D. Pham et al., 2005). 


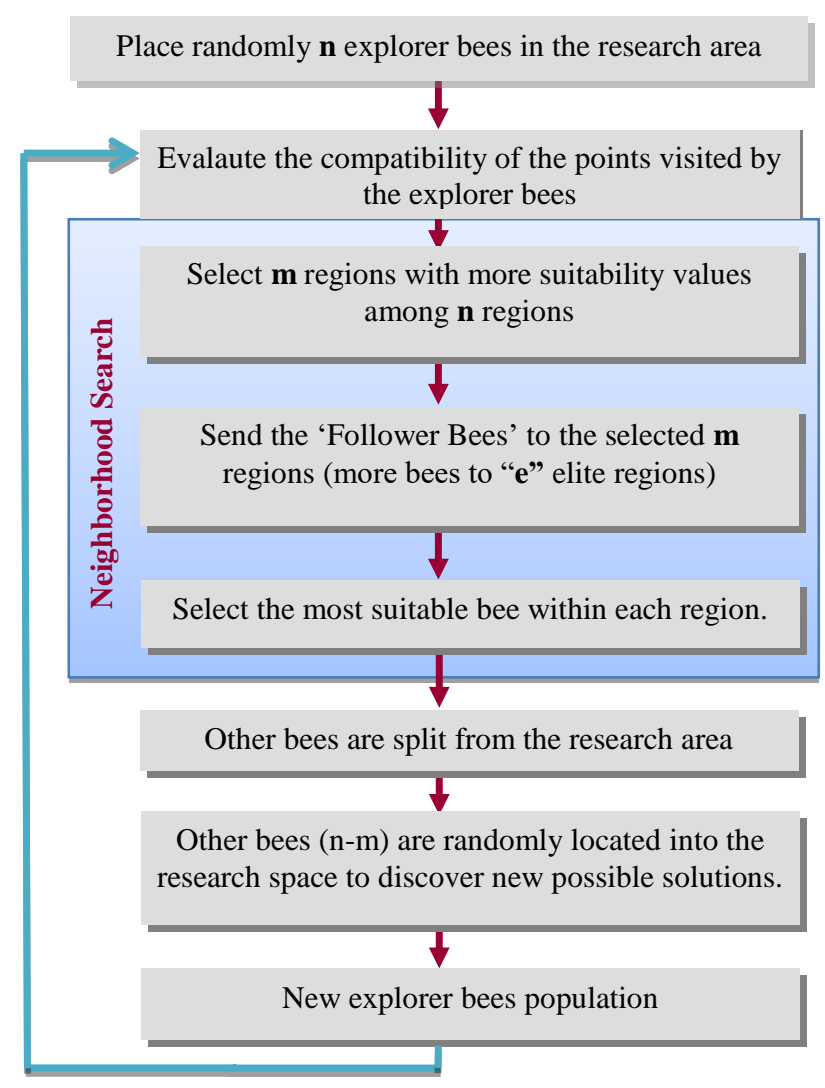

Fig. 3. Flowchart of The Bees Algorithm

In Fig. 4., the block diagram of the SCARA manipulator is shown. The position control of the system is ensured by two optimized closed loop SMC controller based on parameter optimizatiton by The Bees Alghoritm. The system inputs are the torques on the joints $\left(T_{1}\right.$ and $\left.T_{2}\right)$. Outputs of the system are joints' angles $\left(\theta_{1}\right.$ and $\left.\theta_{2}\right)$ and $x-y$ components of the end position. The SMC provide the controller signal for generate torques the SCARA manipulator to move to the desired reference position.

In this study, the pre-designed SMC controller parameters are optimized using The Bees Algorithm to improve control performance. The optimum SMC controller design is aimed to movement of the end of SCARA manipulator to the reference position. Thus, the objective function is defined as the error that occurs in the system response. The objective function equation (J) and the equation of the error (ITAE) are given in (8) and (9) respectively.

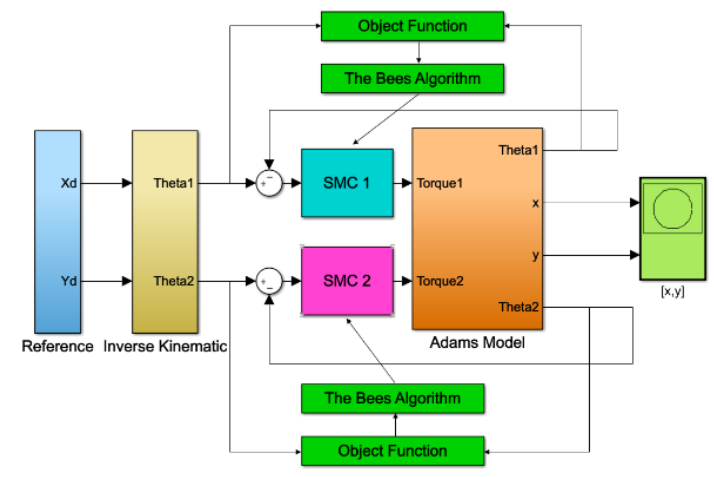

Fig. 4. Block diagram of the system

$$
\begin{gathered}
J=(I T A E)_{t e t a 1}+(I T A E)_{t e t a 2} \\
I T A E=\int_{0}^{\infty} t|e(t)| d t
\end{gathered}
$$

In Table 2 and Table 3, the ranges of optimized controller coefficients and the parameter values of The Bees Algorithm are given, respectively. The experiences obtained from the existing studies on The Bees Algorithm (D. Pham \& Kalyoncu, 2009; D. Pham et al., 2008) in subjects such as determining the objective function, determining the parameters and optimization intervals of The Bees Algorithm are taken into consideration.

\section{Table 2. Range of controller coefficients for The Bees Algorithm}

\begin{tabular}{c|c|c|c|c}
\hline & $\mathbf{K}_{\mathbf{1}}$ & $\mathbf{K}_{\mathbf{2}}$ & $\boldsymbol{\lambda}_{\mathbf{1}}$ & $\boldsymbol{\lambda}_{\mathbf{2}}$ \\
\hline Minimum & 0 & 0 & 0 & 0 \\
\hline Maximum & 1000 & 1000 & 20 & 20 \\
\hline
\end{tabular}

Table 3. The Bees Algorithm parameters

\begin{tabular}{c|c|c|c|c|c|c}
\hline Iter. No. & $\mathbf{n}$ & $\mathbf{m}$ & $\mathbf{e}$ & nep & nsp & ngh \\
\hline 30 & 8 & 4 & 2 & 4 & 7 & 0.1 \\
\hline
\end{tabular}

\subsection{Genetic Algorithm}

The Genetic Algorithm (GA) is a search method used to find approximate solutions to optimization issues. John Holland firstly proposed the GA in 1975, inspired by genetic operations such as mutation, crossover, and selection. The flowchart of the GA is given in Figure 5. This process, shown in the flowchart, is repeated until the appropriate solution or the maximum number of iterations is reached. The population size and crossover and mutation rates given as inputs are the important parameters which affects the performance of the algorithm. The GA may not succeed in a perfect solution because it does not produce a lot of different states to attain the best but it is one of the best algorithm taking time constraints into consideration (Önen, Cakan, \& Ilhan, 2019). 


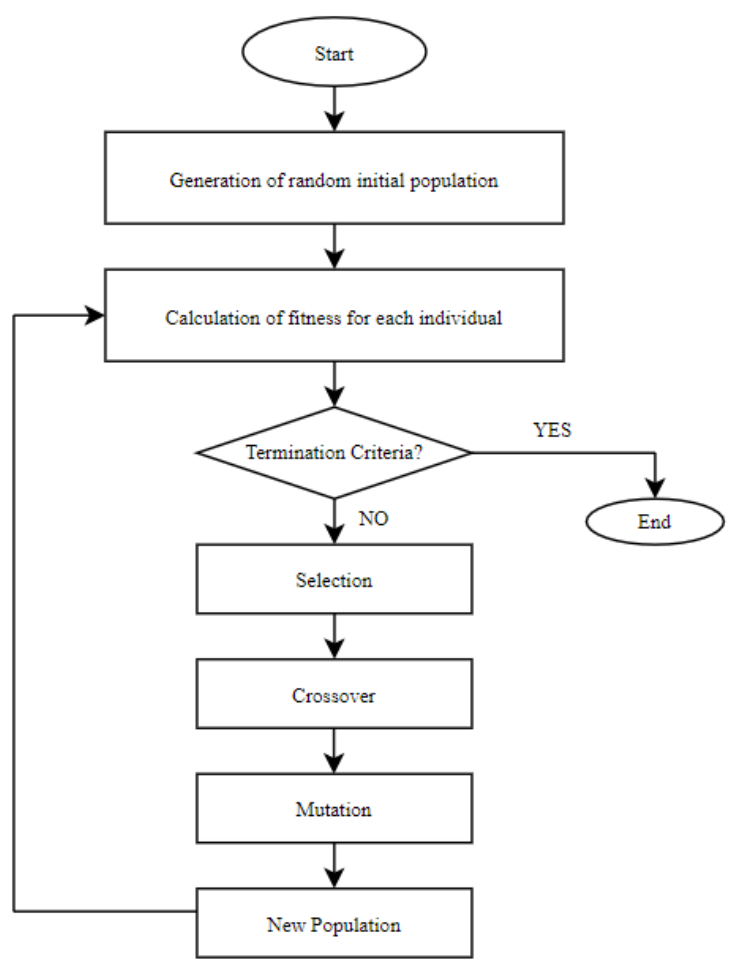

Fig. 5. Flowchart of The Genetic Algorithm

\section{Results and Discussion}

In this part, the controller performance is verified on the simulation. The optimized controller coefficients are given in Table 4. According to these obtained parameters, to verify the output of the controller, the controlled system responses and the simulation outcomes are examined.

Table 4. The optimized controller coefficients

\begin{tabular}{c|c|c}
\hline $\begin{array}{c}\text { Controller } \\
\text { coefficients }\end{array}$ & The Bees Algorithm & Genetic Algorithm \\
\hline$K_{1}$ & 463.0594 & 805.6976 \\
\hline$K_{2}$ & 718.2314 & 660.1463 \\
\hline$\lambda_{1}$ & 6.0897 & 1.7461 \\
\hline$\lambda_{2}$ & 7.9858 & 2.3511 \\
\hline
\end{tabular}

In the system, the robot manipulator is located at the origin in the coordinate system. The position of the end-effector of the robot manipulator is determined as $(0,350)$ point. The robot manipulator is expected to reach the point $(200,50)$ quickly with the help of the controller. The responses of the joints' angles are given in Fig. 6 and Fig. 7, respectively. It can be noticed that the position of the manipulator is adequate for both angles of the joints. In addition, it is seen that The Bees Algorithm approaches to the desired final value faster than the Genetic Algorithm algorithm for response of angles.

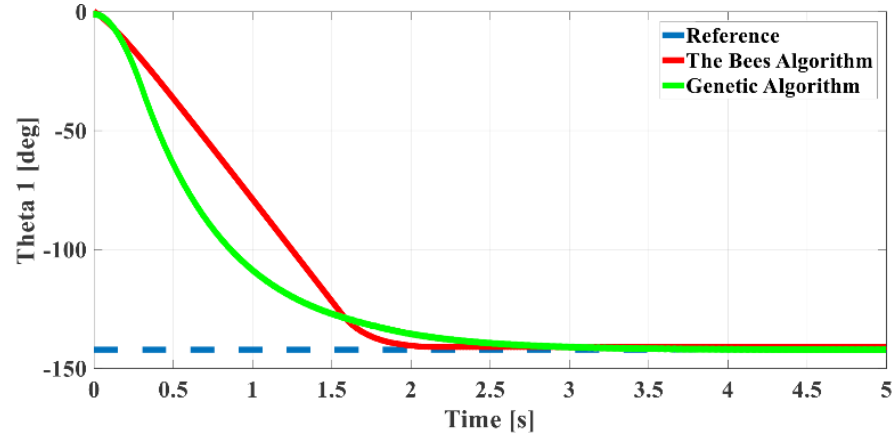

Fig. 6. Control response of $\theta_{1}$

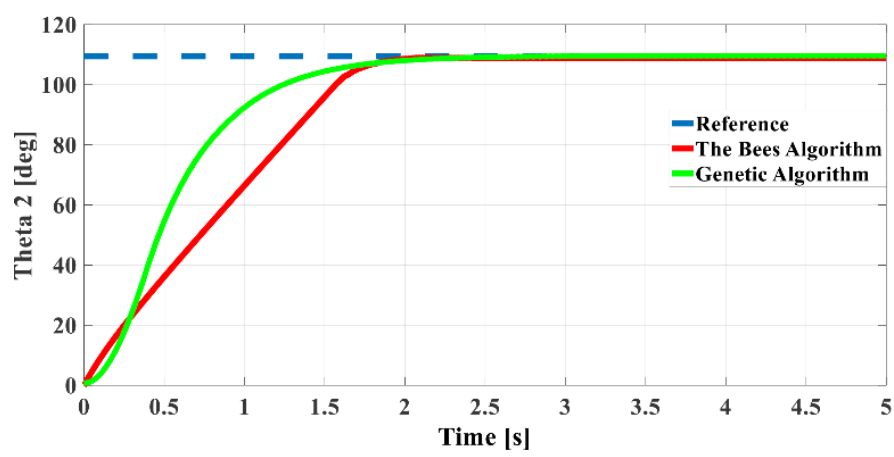

Fig. 7. Control response of $\theta_{2}$

The controller response of the end-effector position of the second link in the $\mathrm{x}-\mathrm{y}$ plane is illustrated separately in Fig. 8 and Fig. 9. It has been observed that the GA is faster than The Bees Algorithm in reaching the $\mathrm{x}-200$ position. On the other hand, it is seen that The Bees Algorithm is faster in reaching the $y-50$ position.

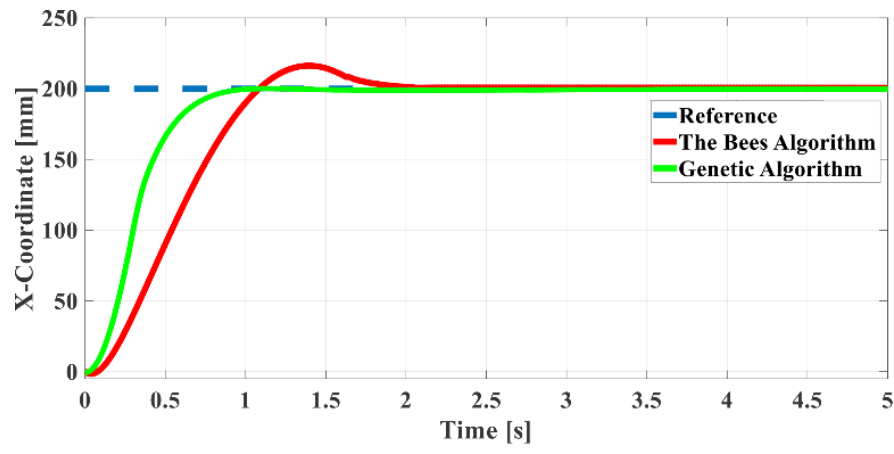

Fig. 8. The end-effector position control in $\mathrm{x}$-coordinate

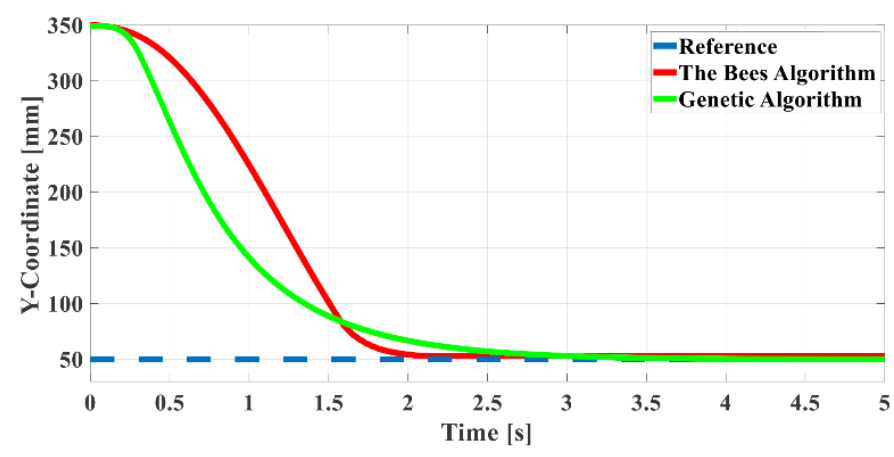

Fig. 9. The end-effector position control in y-coordinate

When the results are evaluated, it is understood that the SMC controller method designed with proposed The Bees Algorithm provide sufficient level of controller performance. When compared with the genetic algorithm, which is a widely 
used meta-heuristic method, it is seen that The Bees Algorithm also gives satisfactory output answers.

\section{Conclusion}

In this study, the position control of a SCARA robot manipulator is performed. A SMC controller is designed to control the position, and the control parameters are firstly obtained by trial and error. Then, The Genetic Algorithm (GA) and The Bees Algorithm are used to determine the SMC parameters. As a result of the simulation studies carried out in Matlab/Simulink environment, it has been observed that both algorithms are successful in determining the SMC control parameters and the robot manipulator comes to the desired reference positions. It is predicted that by changing the parameters of The Bees Algorithm, different configurations can be obtained, different objective functions can be determined, different controllers can be optimized, and successful results can be obtained in experimental and simulation studies. In future studies, it is aimed to compare the control performance obtained as a result of optimization of SMC controller coefficients with other different meta-heuristic algorithms.

\section{Acknowledge}

The authors are thankful to the Konya Technical University Rac-Lab Research Laboratory (www.rac-lab.com) and the Faculty of Engineering, KTO Karatay University.

\section{References}

Beşkirli, M., \& Tefek, M. F. (2019). Parçacık Sürü Optimizasyon Algoritması Kullanılarak Optimum Robot Yolu Planlama. European Journal of Science and Technology, 201-213. doi:10.31590/ejosat.637832.

Bruzzone, L., \& Bozzini, G. (2011). A statically balanced SCARA-like industrial manipulator with high energetic efficiency. Meccanica, 46(4), 771-784.

Demydyuk, M., \& Hoshovs'ka, N. (2019). Parametric Optimization of the Transport Operations of a Two-Link Manipulator. Journal of Mathematical Sciences, 238(2), 174-188.

Erdogmus, P., \& Toz, M. (2012). Heuristic optimization algorithms in robotics Serial and Parallel Robot Manipulators-Kinematics, Dynamics, Control and Optimization (pp. 311-338): InTech Publisher.

Go, S. J., \& Lee, M. C. (2001). Design of a fuzzy-sliding mode controller for a SCARA robot to reduce chattering. Journal of Mechanical Science and Technology, 15(3), 339-350.

İlgen, S. (2019). Robot manipülatörlerin performanslarına yönelik kontrol uygulamalart. Yüksek Lisans Tezi, Lisansüstü Eğitim Enstitüsü, Konya Teknik Üniversitesi.

İlgen, S., Durdu, A., Gülbahçe, E., \& Çakan, A. (2018). Sliding Mode Control of a Two-link Robot Manipulator Using Adams \& Matlab Software. Paper presented at the 2018 6th International Conference on Control Engineering \& Information Technology (CEIT).

Loucif, F., Kechida, S., \& Sebbagh, A. (2020). Whale optimizer algorithm to tune PID controller for the trajectory tracking control of robot manipulator. Journal of the Brazilian Society of Mechanical Sciences Engineering, 42(1), 1-11.
Nadir, B., \& Mohammed, O. (2018). Optimization the Trajectories of Robot Manipulators Along Specified Task. International Journal of Intelligent Engineering Systems, 11(1), 11-19.

Ogulmuş, A. S., Çakan, A., \& Tınkır, M. (2016). Modeling And Position Control Of Scara Type 3D Printer. International Journal Of Scientific Technology Research, 5, 140-143.

Oliveira, J., Oliveira, P. M., Boaventura-Cunha, J., \& Pinho, T. (2017). Chaos-based grey wolf optimizer for higher order sliding mode position control of a robotic manipulator. Nonlinear Dynamics, 90(2), 1353-1362.

Ölgün, M., \& Tilki, U. (2020). Neural Network Based Sliding Mode Controller with Genetic Algorithm for Two Link Robot Manipulator. European Journal of Science and Technology, 120-129. doi:10.31590/ejosat.araconf16.

Önen, Ü., Cakan, A., \& Ilhan, I. (2019). Performance comparison of optimization algorithms in LQR controller design for a nonlinear system. Turkish Journal of Electrical Engineering \& Computer Sciences, 27(3), 1938-1953.

Pham, D., Ghanbarzadeh, A., Koc, E., Otri, S., Rahim, S., \& Zaidi, M. J. T. N., Manufacturing Engineering Centre, Cardiff University, UK. (2005). The bees algorithm.

Pham, D., \& Kalyoncu, M. (2009). Optimisation of a fuzzy logic controller for a flexible single-link robot arm using the Bees Algorithm. Paper presented at the 2009 7th IEEE International Conference on Industrial Informatics.

Pham, D., Koç, E., Kalyoncu, M., \& Tinkır, M. (2008). Hierarchical PID controller design for a flexible link robot manipulator using the bees algorithm. Methods, 25, 32 .

Pham, D. T., Ghanbarzadeh, A., Koç, E., Otri, S., Rahim, S., \& Zaidi, M. (2006). The bees algorithm-a novel tool for complex optimisation problems Intelligent production machines and systems (pp. 454-459): Elsevier.

Qiang, L., Xuhua, S., Ting, L., Xiaoxia, C., \& Jianpei, Z. (2019). Multi-objective optimization based self tuning robot manipulator Controller. Paper presented at the 2019 Chinese Control And Decision Conference (CCDC).

Raheem, F. A., \& Hameed, U. I. (2019). Heuristic D* Algorithm Based on Particle Swarm Optimization for Path Planning of Two-Link Robot Arm in Dynamic Environment. AlKhwarizmi Engineering Journal, 15(2), 108-123.

Sayg1l1, Ç. (2006). Design and animation of a Scara type robot. Master thesis of Mechanical Eng. Dept. of Selçuk University.

Sen, M. A., \& Kalyoncu, M. (2015). Optimisation of a PID controller for an inverted pendulum using The Bees Algorithm. Paper presented at the Applied Mechanics and Materials.

Sen, M. A., \& Kalyoncu, M. (2016). Optimal tuning of a LQR controller for an inverted pendulum using the bees algorithm. J Autom Control Eng, 4(5).

Soltanpour, M. R., \& Khooban, M. H. (2013). A particle swarm optimization approach for fuzzy sliding mode control for tracking the robot manipulator. Nonlinear Dynamics, 74(1), 467-478.

Surapong, N., \& Mitsantisuk, C. (2016). Position and force control of the SCARA robot based on disturbance observer. Procedia Computer Science, 86, 116-119.

Şahin, Y. (2006). PID control application of trajectory control of a Scara type robot. Mater Thesis, Dept. Mechanical Eng. Dept., Selçuk University.

Tarmizi, M. R. (2014). Design and modelling of 6 DOF revolute robot using fuzzy PID controller. Universiti Tun Hussein Onn Malaysia. 
Urrea, C., Cortés, J., \& Pascal, J. (2016). Design, construction and control of a SCARA manipulator with 6 degrees of freedom. Journal of applied research and technology, 14(6), 396-404.

Urrea, C., \& Kern, J. (2012). Modeling, simulation and control of a redundant SCARA-type manipulator robot. International Journal of Advanced Robotic Systems, 9(2), 58.

Wang, N., Liu, J., Wei, S., Xu, Z., \& Zhang, X. (2014). The control system design of a SCARA robot. Paper presented at the International Conference on Intelligent Robotics and Applications.
Zhou, Z., Wang, C., Zhu, Z., Wang, Y., \& Yang, D. (2019). Sliding mode control based on a hybrid grey-wolf-optimized extreme learning machine for robot manipulators. Optik, 185, 364-380. 